Historic, Archive Document

Do not assume content reflects current scientific knowledge, policies, or practices. 

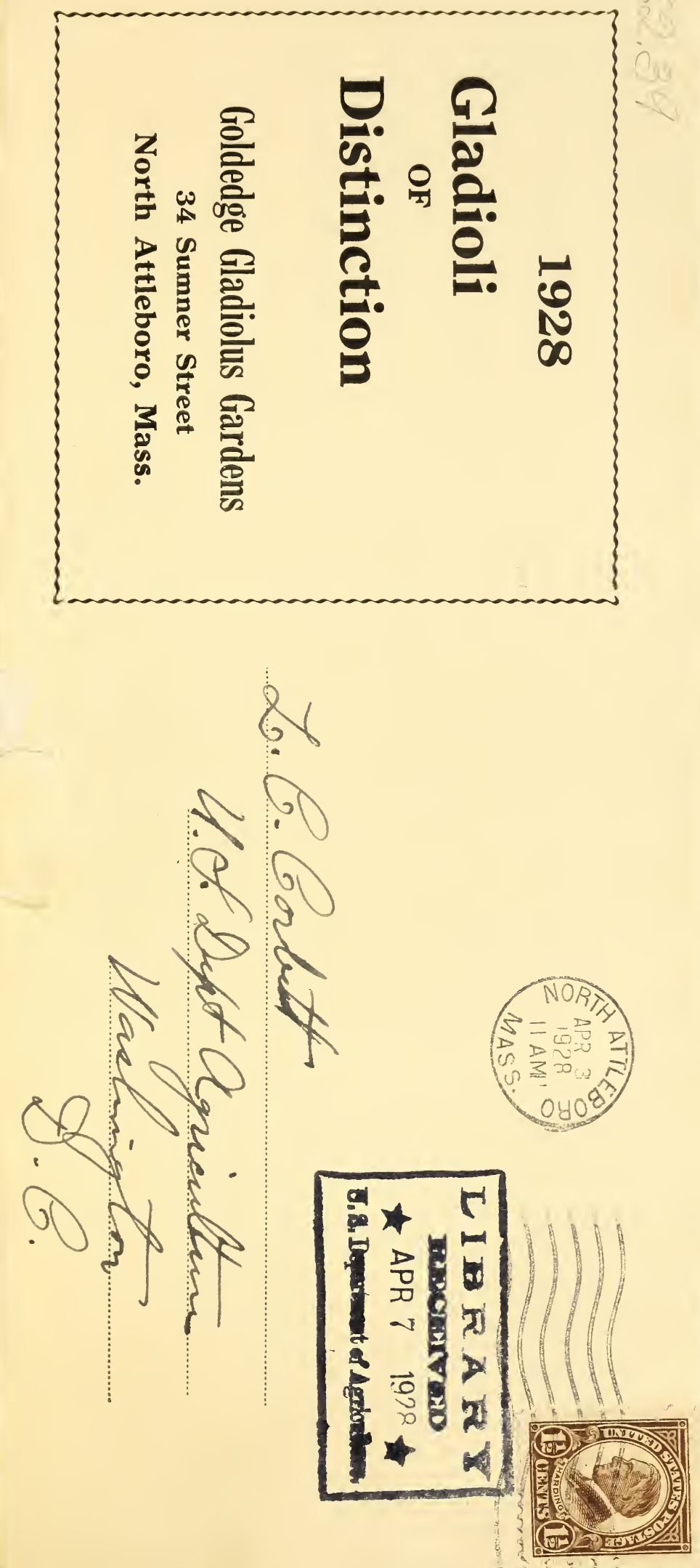


\section{Greetings for 1928}

This year we have decided to try an innovation in our price list. Instead of our usual catalog which costs a large sum to print each year, we are going to issue this folder, and give our customers the benefit of this saving with reduced prices.

You will note that we still feature Mr. L. Merton Gage's introductions; for we believe that his varieties are equal to any now on the market, and better than many offered for much higher prices by other growers. This spring we are moving our gardens to a new location, in order to have ample room for our greatly increased plantings as well as to enlarge the planting each year. May we state here that you are bound to hear from our seedlings as soon as we can grow stock enough to warrant showing them in Boston.

While we have several glowing reports from growers who had our three new varieties for trial last year, we have decided not to place them on sale before 1929. You will find discription of them in our 1927 catalog.

Finally, we wish to thank our many patrons for the splendid support they have given us in the past, and trust we may continue to supply them with Gladiolus of Distinction.

GOLDEDGE GLADIOLUS GARDENS. 
The finest purple glad in existence.

ALICE TIPIAII (K)

sc

Very large beautiful prim of orange safroul.

AlBANIA (Kemp)

Wide open flower of pure glistening white.

A.IERICA. BEATTY (I))

25

Brilliant American Beauty color. Throat creamy color yellow striped with ruby, many open.

ALMA RUBENS (I)

Pale grenadine pink, long spike, many open. New.

BARON HLLOT (Lemoine) Very deep violet blue. The best blue variety.

BOLD WARRIOR (II)

Milk white, lightly tinged lavender on the edge of petals; lips light canary with feathering of ruby. Ruffled.

BLASCO IBANEZ (D) Deep shade of dahlia purple.

BEATRICE (Bill) Eosine pink laid over a cream ground. Has the appearance of soft crepe paper.

CARYEY SYLTA (Dacorah)

Pure snow white, throat slightly penciled lilac. Fine for cut flowers.

CRINKLES (K)

Peach pink. One of Kunderds finest ruffled varieties.

CATHERINE COLEMAX (C) Coral pink with deeper markings in the throat. Splendid.

CRIMSON GLOW (B)

Beautiful deep velvety scarlet. Inmense in size.

CAMEO (Bill)

LaFrance pink over cream ground. Lower petals martius yellow shading to cream. Fine.

CRUEXTES STPERBA (B)

A giant red extra long spike. Visitors pronounce it a wonder.

CAMEO (II)

The blossoms of this variety have a white ground color overlaid with pink and golden yellow.

CAPTAIN BOYYTON (B)

Beautiful light lavender with deeper lavender blotch in the throat, tall spikes many open. 
Delicate rose pink with throat of soft canary yellow.

DREAM (K)

$25 \mathrm{c}$

Large very showy, deep salmon red. Very showy.

DR. BENNETT (D) Deep peach red. A very beautiful gladiolus.

E. G. SHAYLOR (K)

Pure deep rose pink. Quite early.

ELORA (Burbank)

Fine creamy white striped American Beauty.

ELIZABETH TABOR (H)

Large light pink on white ground, with large red blotches on the lower petals. Very early.

\section{ETHELYN (F)}

An unsual orange yellow prim. Very tall and graceful.

\section{EVELYY KIRKLAND (A)}

Beautiful sparkling rose pink. Extra long spikes.

\section{ELROPA (Pfitzner)}

Pure white without any marking whatever. Very beautiful.

\section{FALLEN LEAF (M)}

This is a wonderful color combination of Ashes of Roses.

\section{FAS'TIDIOUS (Bill)}

Large open flowers of shel pink shading to ivory in the throat.

\section{FOR'TLYA (F)}

A wonderful salmon pink. We predict this variety will have a great future when better known.

GIANT NMIPTH (C)

Very large, beautiful light pink. Creamy throat.

GLENDALE (Davis)

Rhodamin purple and Tyrian rose blending harmoniously. A great favorite in our gardens.

\section{GOLI) (Decorah)}

The best yellow in the world, regardless of price and we "don't mean maybe."

GOLDEN MEASURE (Kelway)

Second only to "Gold." A fine yellow. petals brilliant rose carmen.

GLORIANNA (B)

Rich salmon with a wonderful creamy throat. A-1 variety. 
$A$ very unique blending of yellow and salmon. Very distinctive.

HENRY FORI) (D)

$20 \mathrm{c}$

Bright purple introduced at $\$ 200.00$ per bulb.

HAZEL DAWN (Decorah)

Unusual strawberry pink. Long spike of wonderful flowers.

HENRY C. GOEHL (F)

Large white, slightly flushed pink. Deep crimson blotch on the lower petals.

INDIAN MAID (K)

A splendid blending of peach rose and pink.

\section{ILLUMINATOR}

Many large, wide open flowers of brilliant carmen red on tall stately spikes. Stands up well in the hot sun.

JEWELL ( $Z$ )

A rich pink with creamy throat. A wonderful combination of colors.

JACOB VAY BEYREN (H)

Extraordinary violet, self color, well placed on tall spike.

asc

s.oc

$10 \mathrm{e}$

50c

๖c

asc

LE MARECHAL FOCH (V)

Extremely early, large light pink. Splendid.

LOUISE (W)

A very large lavender with velvety maroon blotch.

\section{LOXGFELLOW (Decorah)}

La France pink. Here is a real glad, one you will wish you had bought before.

\section{LICETTE (Bill)}

Fine combination if white and phlox pink. Splendid for cutting.

MARSHALL FOCH (K)

No pink can match this one for size. A sure winner.

MADAM SULLY (De Groat)

Wonderful cream white with beautful red blotches on a yellow throat. Splendid.

\section{IIXG TOY ( K)}

Very refined buff yellow prim. One of Kindreds best.

MR. W. H. PHIPPS (D)

La France pink overlaid with rose salmon. Lower petals striped and speckled with ruby. Diener's masterpiece.

MR. MARK (V)

A real good light blue, deeper in the throat.

\section{MILADY (Bill)}

Tall ruffled variety of creamy white with naples yellow throat with heavy amaranth purple feather. 
A wonderful blending of pink and cream, large flowers and many open. The winner of many awards.

MRS. F. C. PETERS (F)

Beautiful shade of rose lilac with rich crimson blotches. Should be in every collection.

MRS. A. G. NELSON (F)

Beautiful salmon pink with scarlet and pale yellow blotches.

MRS. LEON DOUGLAS (D)

Ground color begonia rose striped with flame scarlet, pale yellow lip slightly speckled ruby. Extremely large flowers on a tall strong spike.

MRS. J. K. ARYSBY (I)

Coral pink penciled with vermilion near the edges. Cream throat speckled with ruby.

MRS. NEWELL VANDERBIL'T (ID)

Light salmon pink heavily ruffled. Throat sulphur yellow mottled with salmon. An A-1 variety.

MRS. ROBERT CUNNINGHAY (ID)

Fine lavender pink. Flowers of the very largest size.

MRS. KR. PRESTGARD (Decorah)

Pure snow white without any trace of markings. Tall, strong plant. The queen of all whites.

MARIE KUNDRED (K)

One of the very earliest whites. Has beautiful pointed petals. A prize winner.

MARRIETI'A (M)

A delicate shade of light salmon shading to burnt orange on the lower petals. Very large flowers.

NORMA TALMADGE (Decorah)

Clear sulphur yellow. Almost self color.

Many large blooms open at one time.

Truly a fine variety.

OPALESCEN'T (Bill)

Wonderful spikes of large pale rose lavender with soft lilac throat lines.

PRIMADONNA (F)

Pure primrose yellow prim. A vase of these are splendid for the table.

PURPLE GLORY (K)

Deepest velvety maroon. One of the largest varieties and finely ruffled.

PRINCE OF WALES (V. Z.)

Very soft light salmon. Very early, fine for cutting.

ROSE ASH (D)

Ashes of Roses. Is much admired by all who visit our gardens.

\section{RICHARD DIENER (D)}

Geranium pink with faint sprinklings of ruby on a creamy yellow center. A wonderful flower. 
- 
RUBINI (H)

Very large salmon. A splendid variety from Holland.

REVUE (Bill)

gec

A very graceful prim of martius yellow shading to delicate pink at the tips of petals.

ROSEMARY (B)

Very unusual pink marked with fine hair lines of lavender rose.

SWEE' LAVENDER (C)

Light lavender, deeper in the throat with purple blotch.

SHEILA (A)

Very early rich salmon. Large blooms, stands up well in the hot sun.

SCARLET WONDER (Cowee)

Mammoth deep scarlet flower on a tall, strong spike.

SALMON BEAUTY (K)

Deep salmon with rich salmon yellow throat.

SOUVENIR (G)

The most flowering gladiolus of purest golden yellow color.

SIBYL (Bill)

Large cream flowers with tips of petals flaked mallow pink.

'THEDA (Bill)

Delicate shrimp pink blending to pinard yellow in the throat. Violet lines on lower petals.

VANITY (Bill)

Delicate La France pink flushed over white ground. Very tall spikes.

QUEEN of the NIGH'T (D)

Deep velvety maroon, almost black. The darkest flower in our gardens.

TEN BULBS FOR THE PRICE OF NINE.

NEW VARIETIES FOR 1928 Introductions of Mr. L. Merton Gage

IRS. ETHELYN ROSE KLEITZ. Prim. grandiflorus, Rose doree with an undertone of white shading to shrimp pink. Lower petals pale chalcidona yellow. Dainty and beautiful. Each ..........

BETTY GAGE. Good size golden yellow flowers of good form and substance. 4 to 6 open at a time, fine spike and a strong grower. Each ..................

MME. EUGENE DECISY. Pale congo pink flaked with peach red; lip straw yellow. Tall straight spike with many flowers open at a time. Each ..............

10c

IRS. H. BROMLEY AMBLER. Orange chrome, the lower petals lit with bright grenadine pink. The richest of all red glads. Each

LEON GAGE CARL. Rose color; throat white with a stripe of amaranth purple thru center of lower petals. Each .......... 
No. 216. Yellow overlaid with grenadine pink: pinard yellow lip with a line of the sanc color thru the center of each petal. Large well open flowers, straight spike. A gorgeous and beautiful combination of these colors. Each ................\$\$..50)

One bulb each of above six novelties \$10.00

ALMA GLCCK. Prim. grandiflorus. Clear, brilliant neach read. There is a splash of scarlet red in the throat surrounded with a corona of sulphur yellow. Excellent for cutting and Landscape use.

1st. size bulbs 15e each. . . . . . . . \$1.50 doz.

2nd. size bulbs 10c each. . . . . . . \$1.00 doz.

A FRICA. Pomegranate purple. There is a large blotch of Bordeaux tipped with white in the throat which appears to be black at a distance. Dozen' $\$ 2.50$. Each ...

BRONZE BEAUTY. Ground color Colonial buff, and so closely overlaid with fine lines of old rose that the effect is a light bronze color. Dozen $\$ 5.00$. Each

CINTHIA CLOUGH. Geranium pink; three lower petals scarlet red with a fine line of white running thru the center. Very fine. Dozen \$3.50. Each ............

DR. JOHX A. MILLS. Very tall spike of good size flowers. White, edged with rose pink with blotches of rose red on three lower petals. Eight flowers open at a time. A strong grower and increases rapidly from bulblets. Very popular with visitors at

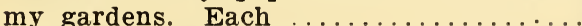

MARJORIE GAGE. A seedling of "Mrs. Frank Pendleton" which it resembles in form. Pure white with the characteristic deep red blotch that makes "Pendleton" so impressively attractive. Dozen \$2.50. Each

MACRICE FULD. This is one of the largest glads yet introduced, measuring from $6^{\prime \prime}$ to $6 \frac{1}{2}$ " across. Always dependable under different kinds of soil and climatic conditions, withstanding the hottest sun without wilting. Fine spike of rich pink, (rose doree) without streaks or blemish with a small broken blotch of tyrian rose on a pure white throat. First Prize for largest flowers, Boston, 1925. Dozen .....

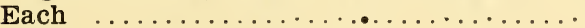
2nd. size, Dozen \$3.50. Each ......... 3rd. size, Dozen \$2.50. Each ..........

MOLLY BURNHAM. Pure white flushed cameo pink; marguerite yellow lip. Very large and beautiful.

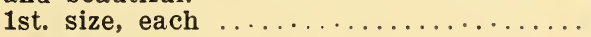

2nd. size, each $\ldots \ldots \ldots \ldots \ldots \ldots \ldots \ldots \ldots$

WH. R. TUCKER. Scarlet shading to purplered, with a purple edge. Quite unusual color combination.

1st. size, each .................

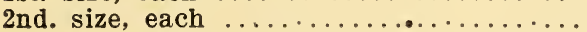




\section{SPECIAL COLLECTION}

This collection we are featuring this season will give any beginner a splendid variety of colors at a great saving over the price you would have to pay if you were to order separately.

One each of the following 15 varieties valued at $\$ 2.50$ mailed postpaid for $\$ 2.00$.

Purple Glory, Richard Diener, Hazel Dawn, Captain Boynton, Gold, Elizabeth Tabor, Fastidious, Marshall Foch, Alma Gluck, Maurice Fuld, Marjorie Gage, Mrs. Frank Morton, Elora, Mrs. Dr. Norton, and Rose Ash.

\section{DIRECTIONS FOR ORDERING AND TERMS}

Bulbs will be shipped postpaid to all points in the United States. Orders will be accepted for as low as fifty cents.

On orders of five dollars or more we will accept twenty-five per cent. with the order and the balance to be paid before the delivery of bulbs. Orders not fully paid on April 1st will be sent C. O. D.

All stock offered subject to prior sale.

We advise you to order early, as all stocks are not of the same size.

We consider bulbs one and one-quarter inches and up good blooming size. If by any chance you should receive stock not true to name, we will consider it a favor if you will notify us at once, and we will replace it two for one. We wish to have our customers satisfied and will make every effort to keep them so.

Remittance must accompany all orders, and should be made payable to John $\mathrm{H}$. Paton, 34 Sumner Street, North Attleborough, Mass. 